Old Dominion University

ODU Digital Commons

2013

Stromatolites and MISS-Differences Between Relatives

N. Noffke

Old Dominion University, nnoffke@odu.edu

S. M. Awramik

Follow this and additional works at: https://digitalcommons.odu.edu/oeas_fac_pubs

Part of the Geochemistry Commons, Geology Commons, Microbiology Commons, Paleontology Commons, and the Sedimentology Commons

Original Publication Citation

Noffke, N., \& Awramik, S. (2013). Stromatolites and MISS-differences between relatives. GSA Today, 23(9), 4-9. doi:10.1130/GSATG187A.1

This Article is brought to you for free and open access by the Ocean \& Earth Sciences at ODU Digital Commons. It has been accepted for inclusion in OES Faculty Publications by an authorized administrator of ODU Digital Commons. For more information, please contact digitalcommons@odu.edu. 


\section{Stromatolites and MISS—Differences between relatives}

\author{
N. Noffke, Old Dominion University, Dept. of Ocean, Earth \& \\ Atmospheric Sciences, Norfolk, Virginia, 23529, USA, nnoffke@ \\ odu.edu; and S.M. Awramik, University of California, Dept. of \\ Earth Science, Santa Barbara, California 93106, USA, awramik@ \\ geol.ucsb.edu
}

\section{ABSTRACT}

Benthic microorganisms form highly organized communities called "biofilms." A biofilm consists of the individual cells plus their extracellular polymeric substances (EPS). In marine and non-marine environments, benthic microbial communities interact with the physical sediment dynamics and other factors in the environment in order to survive. This interaction can produce distinctive sedimentary structures called microbialites. Binding, biostabilization, baffling, and trapping of sediment particles by microorganisms result in the formation of microbially induced sedimentary structures (MISS); however, if carbonate precipitation occurs in EPS, and these processes happen in a repetitive manner, a multilayered build-up can form-stromatolites. Stromatolites and MISS are first found in the early Archean, recording highly evolved microbial activity early in Earth's history. Whereas the stromatolites show enormous morphologic and taxonomic variation, MISS seem not to have changed in morphology since their first appearance. MISS might be the older relative, but due to the lack of well-preserved sedimentary rocks older than 3.5 billion years, the origin of both stromatolites and MISS remains uncertain.

\section{INTRODUCTION}

Benthic microorganisms build a variety of organo-sedimentary structures ("microbialites"; Burne and Moore, 1987) of which the best known are stromatolites. Stromatolites are laminated microbialites (Figs. 1A-1C). Based on the appearance of the microbialite at the mesoscopic scale (= centimeter to millimeter scale; Kennard and James, 1986), microbialites also include thrombolites, dendrolites, and leiolites (Riding, 2000, 2011). Leiolites lack any observable features at the mesoscale; dendrolites have a mesostructure consisting of millimeter- to centimeter-scale "bushes"; and thrombolites have a clotted appearance, with clots often at the millimeter scale.

"Stromatolite" is the anglicized version of "Stromatolith," a term coined by Kalkowsky (1908) that combines the Latin "stroma," meaning layer or bed, and the Greek "lithos," meaning rock. Kalkowsky (1908, p. 68) considered these structures to be the result of the life activity of "niedriger Planzen" (= lower plants). The layering that is so characteristic of stromatolites derives from the microorganisms themselves. Benthic microorganisms do not colonize the sediment surface at random, but rather, trillions of microscopic cells assemble to form an organic layer covering the sedimentary surface like a coherent carpet. Indeed, in tidal flats, where such carpets reach centimeter thickness, one could peel off such a carpet, roll it up, and carry it away. Under the microscope, the microorganisms form a meshwork of filaments, rods, and coccoids in a slimy matrix along with sediment and/or mineral particles; such microorganism-rich carpets therefore are called "microbial mats." Although there are many different types of microbes involved in mat formation, filaments are most important in the construction of stromatolites. The iterative process of sediment trapping and binding, along with carbonate precipitation, forms layer upon layer of stacked microbial mats, producing structures that can reach meters in thickness and beds that can be traced for many kilometers. As such, stromatolites are defined as laminated microbialites produced by sediment trapping, binding, and/or precipitation as a result of the growth and metabolic activity of microorganisms, principally cyanobacteria (Awramik and Margulis, 1974).

However, there is a fifth group of microbialites that are generated by microbial mats: microbially induced sedimentary structures, or MISS (Noffke et al., 1996, 2001) (Figs. 1D-1F). MISS form on siliciclastic substrates with little if any carbonate or other mineral precipitation (Gerdes and Krumbein, 1987; contributions in Hagadorn et al., 1999; Schieber et al., 2007; and Noffke, 2009, 2010; and contributions in Noffke and Chafetz, 2012). MISS include a number of morphologies, though not as many as stromatolites, and range in lateral dimensions from millimeters to many kilometers. MISS are best observed both on sediment surfaces or bedding planes, whereas stromatolites are best observed in vertical section.

It is imperative to understand that the morphology of microbialites - be they stromatolites or MISS — is a result of an overlap of two factors: (1) the intrinsic control (the biology, or genotype and phenotype of the microbenthos that form the structure); and (2) extrinsic factors (size and nature of the sediment and the effect of hydraulic and sediment dynamics, such as waves and currents, etc.). While the shape of a stromatolite or MISS reflects the combined genetic information of all microorganisms in the microbial mat, the shape is also modulated, for example, by waves and currents. The surface of mat-overgrown sediment is the interface along which water movement affects the deposits. This interaction causes that interfacial surface to develop a topography. The topography of the surface (= stromatolite or MISS) is a reflection of the water movement, sediment, and biology of the mat along the interface. However, one of the puzzling features with regard to stromatolites is that there are some distinctive and elaborate morphologies that are restricted in time (e.g., Grey et al., 2011) and in

GSA Today, v. 23, no. 9, doi: 10.1130/GSATG187A.1. 

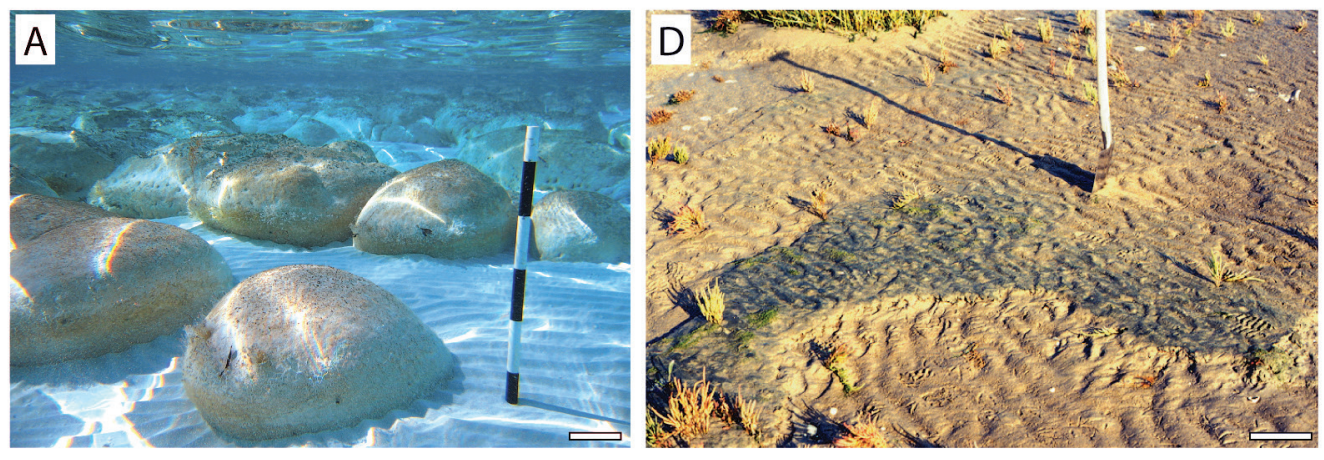

Figure 1. Modern examples of stromatolites and microbially induced sedimentary structures (MISS). (A) Stromatolites north of Carbla Point, Shark Bay, Western Australia. The stromatolites are distinct build-ups of carbonate with vertical relief. The living microbial mat layer colonizes the surface
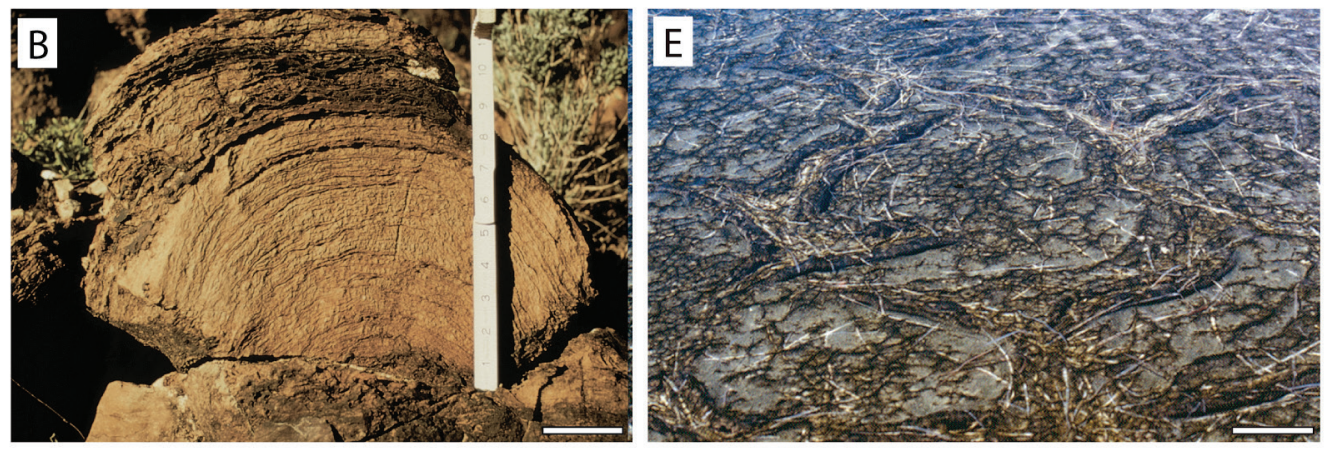
of the stromatolite. Bar scale: $10 \mathrm{~cm}$. (B) Domical stromatolite displaying stack of laminae in vertical section, Brighton Limestone, Cryogenian, South Australia. Bar scale: $5 \mathrm{~cm}$. (C) Baicalia cf. rara from the Shisanlitai Formation, Neoproterozoic, Liaoning Province, China. Bar scale: $2 \mathrm{~cm}$. (D) Tidal flats of Mellum Island, Germany. Erosional remnants and pockets, sometimes called "the siliciclastic answer to stromatolites." The microbial mats are planar, projecting only to a very minor degree from the sedi-

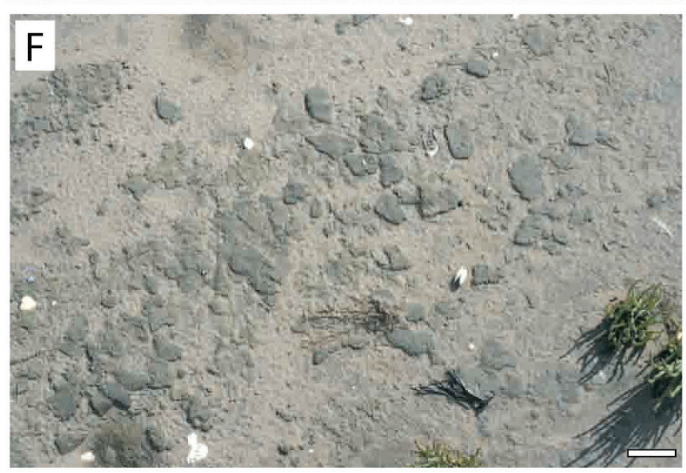
mentary surface. Bar scale: $10 \mathrm{~cm}$. (E) Coastal sabkha Bahar Alouane, Tunisia. Polygonal oscillation cracks form in microbial mats in semi-arid climate zones. Bar scale: $10 \mathrm{~cm}$. (F) Tidal flats of Fishermans Island, Virginia, USA. Microbial mat chips scattered on sandy sediment. Bar scale: $5 \mathrm{~cm}$.

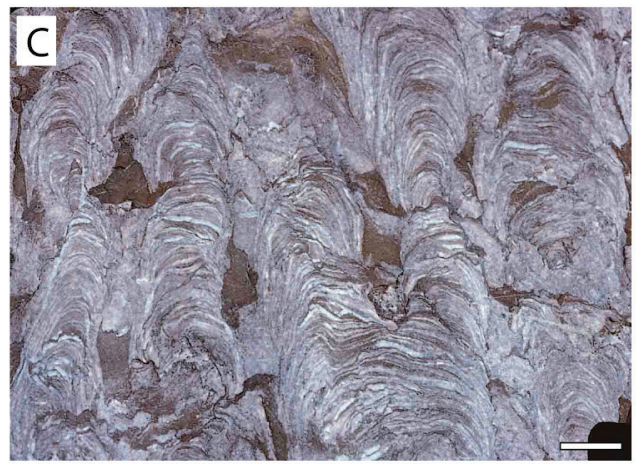

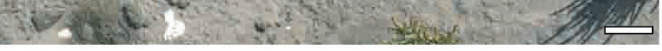

all likelihood reflect time-restricted microbial communities interacting with sediment and hydraulics within the context of an evolving Earth system.

While we can observe how stromatolites and MISS form today, fossil examples of the biogenic structures are known from some of Earth's oldest sedimentary rocks (Hofmann et al., 1999; Awramik, 2006; Noffke, 2010). And since their record covers almost 3500 million years, they provide an opportunity to track their occurrences and look for patterns that reflect both the evolution of microbes and the communities that built these structures, as well as the evolution of conditions on Earth with which the microbes interacted.

\section{SPATIAL DISTRIBUTION OF STROMATOLITES AND MISS}

There are two important divides that make it difficult to understand MISS and stromatolites: a carbonate/siliciclastic divide and a two-dimensional/three-dimensional divide. Although both stromatolites and MISS have a microbial mat as the principlal constructional layer, MISS are generally surface phenomena (twodimensional) and lack a substantial third dimension of stacked layers (mats). Stromatolites on the other hand have a pronounced third dimension, which is due to mineral precipitation and cementation of microbial mats stacked one on top of another. Stromatolites form primarily in environments rich in calcium and bicarbonate, usually at low latitude in marine settings, but at much wider latitudinal settings in lakes, occurring even at $77.5^{\circ} \mathrm{S}$ in perennial ice-covered lakes in Antarctica (Love et al., 1983). MISS occur in siliciclastic and evaporitic environments that are prevalent in low to high latitudes, both marine and terrestrial.

The most famous example of modern stromatolites occurs in the hypersaline Hamelin Pool of Shark Bay, Western Australia. Here, columnar and domical stromatolites, some over a meter in size, as well as smaller structures and a variety of microbial mats (e.g., smooth, blister, tufted), extend from the supratidal to subtidal zones (Jahnert and Collins, 2012). Shark Bay was often used as the modern analog to the rich record of ancient stromatolites, particularly in the Proterozoic (e.g., Walter, 1972). Early studies of the stromatolites interpreted them to be intertidal to supratidal (Logan, 1961), and this was used to interpret the setting of ancient stromatolites (e.g., Laporte, 1963). It wasn't until 1974 that subtidal stromatolites were discovered (Logan et al., 1974). The supratidal forms (the columns that have become iconic) appear to be inactive due to a sea-level drop that exposed the columns (Reid et al., 2003). Hypersalinity and periodic, tidally induced, sediment 
input and movement resulted in reduced metazoan activity, thus permitting the stromatolites to form. Such stressed marine conditions were thought to be the model for the occurrence of other modern examples (supratidal of Andros Island, Bahamas [Monty, 1972]; presence on sabkhas [e.g., Gerdes and Krumbein, 1987]). Later, subtidal stromatolites were discovered, which broadened the depositional setting for ancient analogs. After a subsequent major discovery of multi-meter size subtidal stromatolites forming in marine waters of normal salinity in the Exumas of the Bahamas (Dill et al., 1986), it became clear that other factors affect where modern stromatolites can form. For these subtidal Bahamian examples, environmental stress was involved, but it was the strong tidal currents sweeping across the carbonate platform that controlled initiation and growth of stromatolites. These currents kept carbonate sands highly mobile, and shifting subtidal dunes produced unfavorable conditions for metazoans and macroalgae. Studies on the modern stromatolites of the Bahamas show that the lamination results from two to three mat layers situated at the tops (roofs) of the build-ups. The microbial mat layers form one entity, one ecosystem, and seem to always occur together. Trapping and binding occurs; simultaneously, rapid mineralization of particles in extracellular polymeric substances (EPS) is possibly triggered by heterotrophic microbes. These processes lead to an upward growth of mat-covered sedimentary surfaces, and stromatolites emerge from the seafloor (Reid et al., 2003; Visscher et al., 2000; Andres and Reid, 2006; Dupraz et al., 2009, 2011). Unless buried by shifting subaqueous dunes, the stromatolites continue to grow upward, forming large columns and domes. Less heralded, but significant nevertheless, are spectacular examples of stromatolites forming in lakes, streams, and in spring deposits (e.g., Riding, 2000). Modern MISS develop along the rim of passive continental margins (e.g., the North Atlantic), where they mark shelf regions located within the photic zone, as well as sandy tidal flats, lagoons, and coastal sabkhas. MISS have been beautifully described from terrestrial settings as well, where microbial mats develop in interdune settings, along river shores, in and around lakes, and in swamps (e.g., Eriksson et al., 2000; Prave, 2002; examples in Schieber et al., 2007; Beraldi-Campesi et al., 2009; contributions in Noffke and Chafetz, 2012).

\section{MICROBIAL MATS ARE BIOFILMS}

Technically, microbial mats are biofilms - but of very large size (e.g., Neu, 1994). Biofilms (e.g., Davey and O’Toole, 2000) are highly organized microbial communities comprising many different microorganisms and can include cyanobacteria, bacteria, archaea, and eukaryotic unicells such as diatoms, fungi, etc. The word "biofilm" expresses nicely how those microbial communities look: a thin covering of slime with cells in it. However, what appears like an assemblage of randomly distributed coccoid, filamentous, rod-shaped, and you-name-it microbes is in fact a highly organized organismic arrangement (e.g., Donlan and Costerton, 2002; Stoodley et al., 2002). The microorganisms communicate with each other and move into positions that allow them to interact most efficiently with their neighbors. Metabolic activity is coordinated to ensure the most effective harvesting of nutrients or - in the case of photoautotrophic microbes-light; metabolic products or toxins are actively removed from the biofilm using channels along which the unwanted matter is flushed out with circulating water currents; "decisions" are made by quorum-sensing, involving all members of the biofilm (Decho et al., 2011); in short, a microbial biofilm acts like a societal community rather than just an ecosystem (e.g., Donlan and Costerton, 2002; Stoodley et al., 2002; Decho et al., 2011). The communication and cooperation supports the survival of the biofilm and all members within.

An important component of biofilms and microbial mats is the EPS (Decho et al., 2011). These are highly adhesive mucilages that many microorganisms secrete. The amount of EPS can be so high that the cells literally are embedded in the EPS. EPS are composed primarily of long-chained polysaccharide biomolecules and acidic components. The molecules are complex and arranged in certain ways to offer structural support to the biofilm, to contain the microbes, to allow channels to form where gas and fluids migrate, to absorb nutrients, and to buffer salinity ranges. EPS can also bind calcium ions and, along with bicarbonate in the system, are important for carbonate precipitation (Dupraz et al., 2009). A basic function of EPS is to provide a wobbly, but physically and chemically highly resistant biostructure (Decho et al., 2011; Stoodley et al., 2002).

\section{FUNDAMENTALS OF STRUCTURE FORMATION}

The processes involved in the formation of MISS and stromatolites are involved and complex. We researchers are just scratching the surface of a fully integrated understanding. A fundamental problem for benthic life is to withstand hydraulic and sedimentdynamic reworking. Organisms that colonize the surface of aquatic deposits must cope with turbulent wave action, entrainment by currents, abrasive saltation, or even burial by mineral grains. How can microbenthos escape turbulence, erosion, and deposition? Microbial mats that form MISS and stromatolites share some fundamental microorganism-sediment interactions. In response to sudden erosive shear caused by water motion, the EPS of a microbial mat change their molecular structure within a fraction of a second (e.g., Stoodley et al., 2002; Paterson et al., 2010). The microbial mat is not eroded, nor are mineral grains ripped-off that are enclosed within the microbial mat matrix. Such sediment fixation by the biofilm or mat is called biostabilization; it reduces the effect of erosion.

During deposition of sedimentary particles, microorganisms can baffle the water current, causing sedimentary particles to be deposited; the microbially triggered fall-out takes place in currents of velocities that otherwise (without the presence of microbes) would hold the sedimentary particles in suspension. The grains are trapped in the tangle of filaments and glued to the mat surface by the EPS. Baffling and trapping is a microbially mediated type of deposition.

Baffling, trapping, and biostabilization form a dynamic window for the microbial mats to establish themselves and to withstand dynamic environmental stresses. Basically, the microbial mats broaden (bioengineer) this window by reducing erosion and by controlling depositional rates (Noffke, 2010). Studies on MISS show that binding is neither biostabilization (which is triggered by erosion), nor is it baffling or trapping (which is triggered by deposition). Binding is the active formation of a mat network by the cooperative effort of microbial cells during times of sedimentary and hydraulic quiescence. Grains trapped during a preceding depositional event 
can be rearranged in the mat matrix, sometimes to channel light into deeper portions of the microbial mat. Growth (biomass enrichment by cell replication and EPS production) is taking place, if nutrients are readily available and supplied in abundance.

Do these physical microbe-sediment interactions cause MISS and stromatolites? In the case of the MISS, yes. But in stromatolites, another structure-forming process is added: a chemical process. In stromatolite-forming microbial mats, mineral particles (commonly carbonates) are found forming in the EPS. Laboratory studies show that the particles precipitate in the organic matrix of the EPS; the EPS provide micro-domains, where the architecture of biomolecules offers nucleation sites for carbonate precipitation that can be initiated by the activity of heterotrophic microbes (Dupraz et al., 2009).

In summary, the bulk of a stromatolite is initially formed by biomass, trapped and biostabilized sediment, plus precipitated minerals; later, the biomass is almost completely degraded. Due to the mineral precipitation in their EPS, stromatolites tend to grow upward, whereas MISS remain planar (Fig. 2).
MISS and stromatolites finally become fossils, because the organic matter of the original microbial community lithifies in situ (Krumbein et al., 1979; Schule-Lam et al., 1996; see review in Noffke, 2010). Heterotrophic members of the microbial mat (biofilm) mineralize organic matter. By mineralization in this context, we refer to the step-by-step breakdown of large biomolecules into smaller and smaller chemical compounds and ions, some of which become available to heterotrophic microorganisms, while others, such as the ions, react with the ions of the surrounding water, and mineral precipitates form (Visscher and Stolz, 2005).These initial precipitates in biofilms are usually hydrated. During successive diagenetic alteration, the "amorphous" phases recrystallize into mineralic substance with a crystalline structure often acting as a cement. Dependent on the water chemistry, the structures may include pyrite, aragonite, calcite, dolomite, hematite, titanium oxide, and other minerals. For stromatolites, the nearly penecontemporaneous mineralization of the mats with carbonate supports the preservation. Modern stromatolites may include aragonite and calcite (Reid et al., 2000) or even dolomite (Vasconcelos and McKenzie, 1997) and gypsum (Douglas et al., 2008).
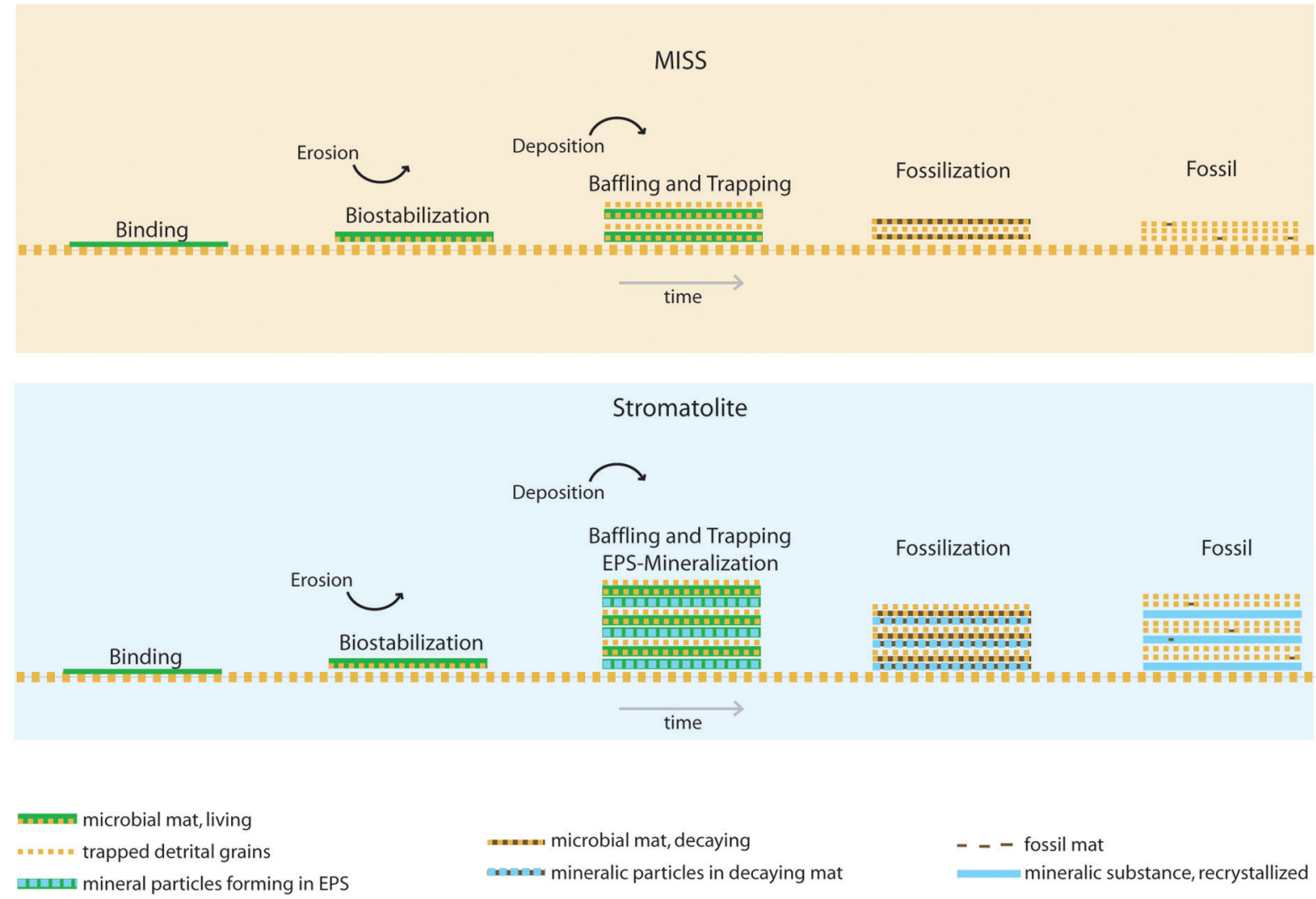

Figure 2. Formation of microbially induced sedimentary structures (MISS) versus stromatolites. Top: The microbial mat overgrows the sedimentary surface and incorporates some of the sedimentary grains. The process of individual microbes actively assembling to form a microbial mat fabrics is called "binding." During episodes of erosion, the microbial mat biostabilizes its substrate; during episodes of deposition of sediment, baffling and trapping accumulates sedimentary particles on the microbial mat surface. Bottom: In stromatolites, another process is added. Here, mineral particles (usually carbonates) form within the extracellular polymeric substance (EPS-mineralization). In the formation of MISS, the processes of binding, biostabilization, baffling, and trapping elevate the mat-covered sedimentary surface somewhat; the amount of precipitated minerals typical for stromatolites contributes significantly to their positive topography. Later, the MISS- or stromatolite-forming microbial mats fossilize - that is, the organic matter is replaced by minerals. In stromatolites, however, the EPSprecipitated mineral particles now recrystallize and contribute to the layering (lamination) characteristic for most stromatolites. MISS commonly lack this lamination. Note that there are also stromatolites predominantly formed by mineral precipitation with no or very minor detrital sediment in them. 
TEMPORAL DISTRIBUTION OF STROMATOLITES AND MISS AND THEIR SIGNIFICANCE

Both MISS and stromatolites are among the oldest evidence of life on Earth. Their temporal distribution ranges from the Early Archean to the present day. It must be pointed out that establishing the biogenicity of the most ancient MISS and stromatolites is not straightforward and relies primarily on multiple lines of evidence and comparisons with modern and other fossil analogs (Awramik and Grey, 2005). The occurrence of many, time-restricted, distinctive morphologies that have been given binomial names makes stromatolites helpful tools in biostratigraphic zonation, particularly in the Proterozoic (Cloud and Semikhatov, 1969; Grey et al., 2011). More than 1,100 taxa of stromatolites have been described in the literature. Stromatolite taxa are established based on a combination of features, including the overall shape, the nature and geometry of laminae, and lamina microstructure. These named stromatolites have a "morphological theme," meaning there is similarity among nearest neighbor stromatolites in the biostrome or bioherm. Stromatolites show greatest morphological diversity in the Proterozoic, particularly the late Mesoproterozoic (Awramik and Sprinkle, 1999) (Fig. 3). This diversity pattern likely reflects unique combinations of microbial biology (genetics), interactions with non-microbial mat organisms, and conditions on Earth.

Prokaryotes that build microbialites exist in biofilm cooperatives, not as solitary organisms. Although many can survive outside of the community, it is the cooperative that they create in which they increase their survival possibilities, strategically manipulate their environment, and develop survival strategies by chemical communication and quorum sensing (Noffke et al., 2013). Chemical clues for gene expression have been recognized in bacteria in biofilms that change the structure of the biofilm (Davies et al., 1998). Therefore, it is not the individual microbe that controls structure formation; it is the entire biofilm and all genetic information and resulting phenotypes that form that complex consortium. At some point in the evolution of prokaryotes (bacteria and archaea), EPS caused the precipitation of mineral particles. Stromatolites were born. Structures we would call stromatolites were described as early as the sixteenth century (Krumbein et al., 2003) and have been given binomial names since 1883 (Hall, 1883). MISS seem not to have changed in morphology over time. Erosional remnants and pockets, polygonal oscillation cracks, and mat chips (Figs. 1D-1F) and a multitude of other MISS are nearly identical from the early Archean to today. MISS might be Earth-historically older than stromatolites, but because the MISS-producing biofilms never evolved EPS-controlled mineral precipitation, they never produced the diversity of their relatives. However, the oldest stromatolites and MISS infer that the highly organized, cooperative way of life in prokaryotes had already evolved by the time of Earth's oldest sedimentary record.

\section{ACKNOWLEDGMENTS}

S. Awramik thanks Western Australia's Dept. of Conservation and Land Management (now Dept. of Parks and Wildlife) for permission to conduct research in Shark Bay. N. Noffke acknowledges support from the NSF Sedimentary Geology and Paleobiology Program, the NASA Exobiology and Evolutionary Biology Program, the NASA Mars Exploration Rover Program, and the NASA Astrobiology Institute for her research on MISS. We both thank the Geological Survey of Western Australia (GSWA) for field support

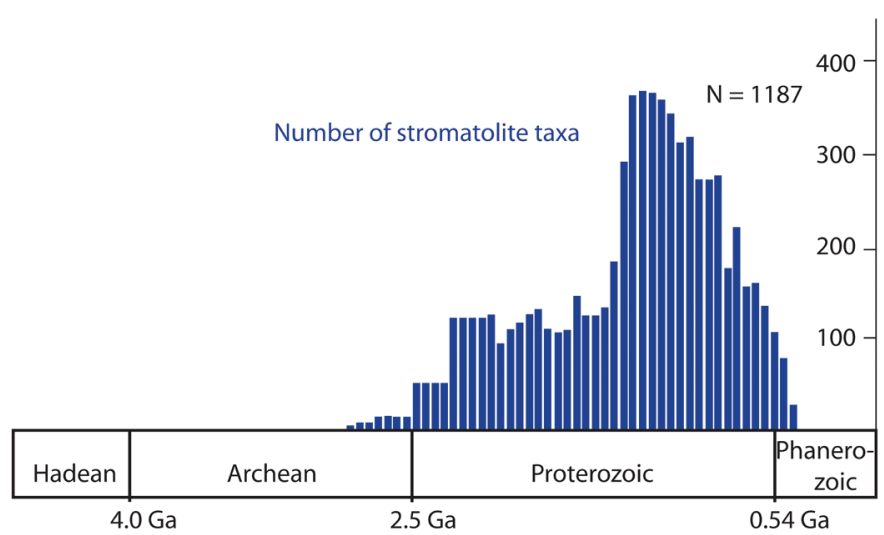

Figure 3. Diversity of taxa ("forms," in the literature, which are roughly equivalent to form species) of stromatolites through time. This graph plots the number of forms per 50-million-year interval and is redrawn from Fig. 2 in Awramik and Sprinkle (1999) using the same dataset. The high diversity of stromatolites during the Mesoproterozoic, 1600 to $1000 \mathrm{Ma}$, is remarkable.

and Kath Grey (GSWA) for discussions on all aspects of microbialites. Two anonymous reviewers provided highly valuable suggestions. We thank GSA Today for inviting us to write this paper.

\section{REFERENCES CITED}

Andres, M.S., and Reid, R.P., 2006, Growth morphologies of modern marine stromatolites: A case study from Highborne Cay, Bahamas: Sedimentary Geology, v. 185, p. 319-328.

Awramik, S.M., 2006, Respect for stromatolites: Nature, v. 441, p. 700-701.

Awramik, S.M., and Grey, K., 2005, Stromatolites: Biogenicity, biosignatures, and bioconfusion, in Hoover, R.B., Levin, G.V., Rozanov, A.Y., and Gladstone, G.R., eds., Proceedings of the SPIE (International Society for Optics and Photonics), Astrobiology and Planetary Missions: SPIE abstracts, v. 5906, p. 59060P-1-59060P-2, doi: 10.1117/12.625556.

Awramik, S.M., and Margulis, L., 1974, Definition of stromatolite, in Walter, E., ed., Stromatolite Newsletter, v. 2, p. 5.

Awramik, S.M., and Sprinkle, J., 1999, Proterozoic stromatolites: The first marine evolutionary biota: Historical Biology, v. 13, p. 241-253.

Beraldi-Campesi, H., Hartnett, H.E., Anbar, A., Gordon, G.W., Garcia-Pichel, F., 2009, Effect of biological soil crusts on soil elemental concentrations: Implications for biogeochemistry and as traceable biosignatures of ancient life on land: Geobiology, v. 7, p. 348-359.

Burne, R.V., and Moore, L.S., 1987, Microbialites: Organosedimentary deposits of benthic microbial communities: Palaios, v. 2, p. 241-254.

Cloud, P.E., and Semikhatov, M.A., 1969, Proterozoic stromatolite zonation: American Journal of Science, v. 267, p. 1017-1061.

Davey, M.E., and O’Toole, G.A., 2000, Microbial biofilms: From ecology to molecular genetics: Microbiology and Molecular Biology Reviews, v. 64, p. 847-867.

Davies, D.G., Parsek, M.R., Pearson, J.P., Iglewski, B.H., Costerton, J.W., and Greenberg, E.P., 1998, The involvement of cell-cell signals in the development of a bacterial biofilm: Science, v. 280, p. 295-299.

Decho, A., Frey, R.L., and Frey, J.L., 2011, Chemical challenges to bacterial AHL signaling in the environment: Chemical Reviews, v. 111, p. 86-99.

Dill, R.F., Shinn, E.A., Jones, A.T., Kelley, K., and Steinen, R.P., 1986, Giant subdtidal stromatolites forming in normal salinity waters: Nature, v. 324, p. 55-58.

Donlan, R.M., and Costerton, J.W., 2002, Biofilms: Survival mechanisms of clinically relevant microorganisms: Clinical Microbiology Reviews, v. 15, p. 167-193.

Douglas, S., Abbey, W., Mielke, R., Conrad, P., and Kanik, I., 2008, Textural and mineralogical biosignatures in an unusual microbialite from Death Valley, California: Icarus, v. 193, p. 620-636. 
Dupraz, C., Reid, P.R., Braissant, O., Decho, A.W., Norman, R.S., and Visscher, P.T., 2009, Processes of carbonate precipitation in modern microbial mats: Earth Science Reviews, v. 96, p. 141-162.

Dupraz, C., Reid, R.P., and Visscher, P.T., 2011, Microbialites, modern, in Reitner, J., and Thiel, V., eds, Encyclopedia of Geobiology, Encyclopedia of Earth Science Series: Berlin, Springer, p. 653-654.

Eriksson, P.G., Simpson, E.L., Eriksson, K.A., Bumby, A.J., Steyn, G.L., and Sarkar, S., 2000, Muddy roll-up structures in siliciclastic interdune deposits of the ca. 1.8 Ga Waterberg group, South Africa: Palaios, v. 15, p. 177-183.

Gerdes, G., and Krumbein, W.E., 1987, Biolaminated Deposits: Heidelberg, Springer, $109 \mathrm{p}$.

Grey, K., Hill, A.C., and Calver, C., 2011, Biostratigraphy and stratigraphic subdivision of Cryogenian successions of Australia in a global context, in Arnaud, E., Halverson, G.P., and Shields-Zhou, G., eds., The Geological Record of Neoproterozoic Glaciations: London, Geological Society Memoir 36, p. 113-134.

Hagadorn, W., Pflueger, F., and Bottjer, D.J., editors, 1999, Unexplored microbial worlds: Palaios, v. 14, 96 p.

Hall, J., 1883, Cryptozoon n.g.; Cryptozoon proliferum n. sp.: New York State Museum, Annual Report, v. 36, plate 6 and caption.

Hofmann, H.J., Grey, K., Hickman, A.H., and Thorpe, R.I., 1999, Origin of 3.45 Ga coniform stromatolites in the Warawoona Group, Western Australia: GSA Bulletin, v. 111, p. 1256-1262.

Jahnert, R.J., and Collins, L.B., 2012, Characteristics, distribution and morphogenesis of subtidal microbial systems in Shark Bay, Australia: Marine Geology, v. 303-306, p. 115-136.

Kalkowsky, E., 1908, Oolith und Stromatolith in norddeutschen Buntsandstein: Zeitschrift der Deutschen Gesellschaft für Geowissenschaften, v. 60, p. 68-125.

Kennard, J.M., and James, N.P., 1986, Thrombolites and stromatolites: Two distinct types of microbial structures: Palaios, v. 1, p. 492-503.

Krumbein, W.E., 1979, Photolithotrophic and chemoorganotrophic activity of bacteria and algae as related to beach rock formation and degradation (Gulf of Aquaba, Sinai): Journal of Geomicrobiology, v. 1, p. 139-203.

Krumbein, W.E., Brehm, U., Gerdes, G., Gorbushina, A.A., Levit, G., and Palinska, K.A., 2003, Biofilm, biodictyon, biomat—biolaminites, oolites, stromatolites—geophysiology, global mechanism, parahistology, in Krumbein, W.E., Paterson, D.M., and Zavarzin, G.A., eds., Fossil and Recent Biofilms: Dordrecht, Kluwer, p. 1-27.

Laporte, F.F., 1963, Codiacean algae and algal stromatolites of the Manlius Limestone (Devonian) of New York: Journal of Paleontology, 37, p. 643-647.

Logan, B.W., 1961, Cryptozoan and associated stromatolites from the Recent of Shark Bay, Western Australia: Journal of Geology, v. 69, p. 517-533.

Logan, B.W., Hoffman, P., and Gebelein, C.D., 1974, Algal mats cryptalgal fabrics and structures, Hamelin Pool, Western Australia: American Association of Petroleum Geologists Memoir 13, p. 38-84.

Love, F.G., Simmons, G.M., Parker, B.C., Wharton, R.A., and Seaburg, K.G., 1983, Modern conophyton-like microbial mats discovered in Lake Vanda, Antarctica: Geomicrobiology Journal, v. 3, p. 33-48.

Neu, T.R., 1994, Biofilms and microbial mats, in Krumbein, W.E., Paterson, D.M., and Stal, L., eds., Biostabilization of Sediments: Oldenburg, BISVerlag, p. 6-16.

Monty, C.L.V., 1972, Recent algal stromatolitic deposits, Andros Island, Bahamas; Preliminary report: Geologische Rundschau, v. 61, p. 742-783.

Noffke, N., 2009, The criteria for the biogeneicity of microbially induced sedimentary structures (MISS) in Archean and younger, sandy deposits: Earth Science Reviews, v. 96, p. 173-180, doi: 10.1016/j.earscirev.2008 .08 .002 .
Noffke, N., 2010, Geobiology: Microbial Mats in Sandy Deposits from the Archean Era to Today: Heidelberg, Springer, 196 p.

Noffke, N., and Chafetz, H., editors, 2012, Microbial Mats in Siliciclastic Depositional Systems through Time: SEPM (Society for Sedimentary Geology) Special Publication 101, 200 p.

Noffke, N., Gerdes, G., Klenke, T., and Krumbein, W.E., 1996, Microbially induced sedimentary structures-Examples from modern sediments of siliciclastic tidal flats: Zentralblatt Geologie und Palaontologie, v. 1, p. 307-316.

Noffke, N., Gerdes, G., Klenke, T., and Krumbein, W.E., 2001, Microbially induced sedimentary structures-A new category within the classification of primary sedimentary structures: Journal of Sedimentary Research, v. 71, p. 649-656.

Noffke, N., Decho, A.W., and Stoodley, P., 2013, Slime though time: The fossil record of prokaryote evolution, Palaios, v. 28, p. 1-5.

Paterson, D.M., Aspden, R.J., and Reid, R.P., 2010, Biodynamics of modern marine stromatolites, in Seckbach, J., and Oren, A., eds., Microbial Mats: Modern and Ancient Microorganisms in Stratified Systems: Cellular Origin, Life in Extreme Habitats and Astrobiology: New York, Springer, p. 223-235.

Prave, A.R., 2002, Life on land in the Proterozoic: Evidence from the Torrodonian rocks of Northwest Scotland: Geology, v. 30, p. 811-814.

Reid, R.P., Visscher, P.T., Decho, A.W., Stolz, J.F., Bebout, B.M., Dupraz, C., MacIntyre, I.G., Paerl, H.W., Pinckney, J.L., Prufert-Bebout, L., Steppe, T.F., and Des Marais, D.J., 2000, The role of microbes in accretion, lamination and early lithification of modern marine stromatolites: Nature, v. 406, p. 989-992.

Reid, R.P., James, N.P., Macintyre, I.G., Dupraz, C.P., and Burne, R.V., 2003, Shark Bay stromatolites: Microfabrics and reinterpretation of origins: Facies, v. 49, p. 45-53.

Riding, R., 2000, Microbial carbonates: The geological record of calcified bacterial-algal mats and biofilms: Sedimentology, v. 47 (supplement 1), p. 179-214.

Riding, R., 2011, Microbialites, stromatolites, and thrombolites, in Reitner, J., and Thiel, V., eds. Encyclopedia of Geobiology, Encyclopedia of Earth Sciences Series: Springer Netherlands, p. 635-654.

Schieber, J., Bose, P.K., Eriksson, P.G., Banerjee, S., Sarkar, S., Alterman, W., and Catuneanu, O., 2007, Atlas of Microbial Mat Features Preserved within the Siliciclastic Rock Record: Atlases in Geosciences, Amsterdam, Elsevier, 311 p.

Schulze-Lam, S., Fortina, D., Davisa, B.S., and Beveridge, T.J., 1996, Mineralization of bacterial surfaces: Chemical Geology, v. 132, p. 171-181.

Stoodley, P., Sauer, K., Davies, D.G., and Costerton, J.W., 2002, Biofilms as complex differentiated communities: Annual Reviews in Microbiology, v. 56, p. $187-209$.

Vasconcelos, C., and McKenzie, J.A., 1997, Microbial mediation of modern dolomite precipitation and diagenesis under anoxic conditions (Lagoa Vermelha, Rio de Janeiro, Brazil): Journal of Sedimentary Research, v. 67, p. 378-390.

Visscher, P., and Stolz, J., 2005, Microbial mats as bioreactors: Populations, processes, and products: Paleogeography, Paleoclimatology, Paleoecology, v. 218 , p. $87-100$.

Visscher, P.T., Reid, R.P., and Bebout, B.M., 2000, Microscale observations of sulfate reduction: Correlation of microbial activity with lithified micritic laminae in modern marine stromatolites: Geology, v. 28, p. 919-922.

Walter, M.R., 1972, Stromatolites and the Biostratigraphy of the Australian Precambrian and Cambrian: London, The Palaeontological Association, Special Paper 11, 190 p.

Manuscript received 3 May 2013; accepted 1 July 2013. 